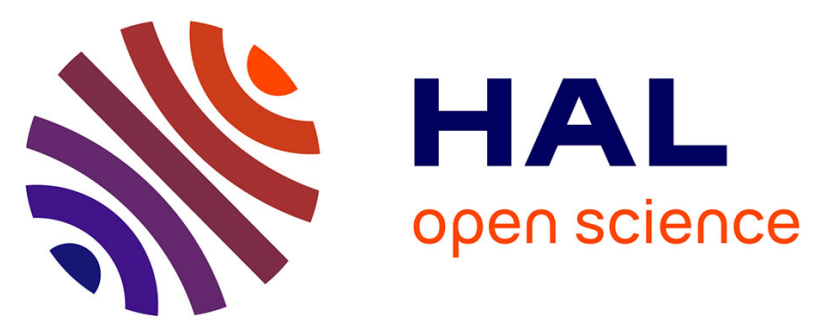

\title{
17O-excess and d-excess of atmospheric water vapor measured by cavity ring-down spectrometry: Evidence of a matrix effect and implication for the calibration procedure
}

Claudia Voigt, Christine Vallet-Coulomb, Clément Piel, Anne Alexandre

\section{To cite this version:}

Claudia Voigt, Christine Vallet-Coulomb, Clément Piel, Anne Alexandre. 17O-excess and d-excess of atmospheric water vapor measured by cavity ring-down spectrometry: Evidence of a matrix effect and implication for the calibration procedure. Rapid Communications in Mass Spectrometry, 2021, $10.1002 / \mathrm{rcm} .9227$. hal-03539023

\section{HAL Id: hal-03539023 \\ https://hal.science/hal-03539023}

Submitted on 5 Feb 2022

HAL is a multi-disciplinary open access archive for the deposit and dissemination of scientific research documents, whether they are published or not. The documents may come from teaching and research institutions in France or abroad, or from public or private research centers.
L'archive ouverte pluridisciplinaire HAL, est destinée au dépôt et à la diffusion de documents scientifiques de niveau recherche, publiés ou non, émanant des établissements d'enseignement et de recherche français ou étrangers, des laboratoires publics ou privés. 


\title{
${ }^{17} \mathrm{O}$-excess and d-excess of atmospheric water vapor measured by cavity ring-down spectrometry: Evidence of a matrix effect and implication for the calibration procedure
}

\author{
Claudia Voigt ${ }^{1}$, Christine Vallet-Coulomb ${ }^{1},{\text { Clément } \text { Piel }^{2} \text {, Anne Alexandre }}^{1}$
}

$5 \quad{ }^{1}$ Aix Marseille Univ, CNRS, IRD, INRAE, CEREGE, Aix-en-Provence, France

${ }^{2}$ ECOTRON Européen de Montpellier, UAR 3248, Centre National de la Recherche Scientifique (CNRS), Campus de Baillarguet, Montferrier-sur-Lez, France

Correspondence to: Claudia Voigt (voigt@cerege.fr)

\section{Abstract.}

10 RATIONALE: Producing robust high frequency time series of raw atmospheric water vapor isotope data by laser spectrometry requires accurate calibration. Especially, the chemical composition of the analyzed sample gas can cause isotope bias. This study assesses the matrix effect on calibrated $\delta^{17} \mathrm{O}, \delta^{18} \mathrm{O}, \delta^{2} \mathrm{H},{ }^{17} \mathrm{O}$-excess, and d-excess values of atmospheric water vapor.

METHODS: A Picarro L2140-i cavity ring-down spectrometer combined with an autosampler and a vaporizer is used to

15 analyze $\delta^{17} \mathrm{O}, \delta^{18} \mathrm{O}, \delta^{2} \mathrm{H},{ }^{17} \mathrm{O}$-excess and d-excess of two water standards. Isotope data obtained using synthetic air and dry ambient air as carrier gas at water mixing ratios ranging from 2000 to 30000 ppmv are compared. Based on the results, atmospheric water vapor measurements are calibrated. The expected precision is estimated by Monte Carlo simulation.

RESULTS: The dry air source strongly impacts raw isotope values of the two water standards, but has no effect on the mixing ratio dependency functions. When using synthetic air, $\delta^{17} \mathrm{O}, \delta^{18} \mathrm{O}$ and ${ }^{17} \mathrm{O}$-excess of calibrated atmospheric water

20 vapor are overestimated by $0.6 \%, 0.7 \%$, and 217 per meg, respectively, while $\delta^{2} \mathrm{H}$ and d-excess are underestimated by $1.5 \%$ and $7.3 \%$. Optimum precisions for the calibrated $\delta^{17} \mathrm{O}, \delta^{18} \mathrm{O}, \delta^{2} \mathrm{H},{ }^{17} \mathrm{O}$-excess and d-excess values and 12 -min integration time are $0.02 \%, 0.03 \%, 0.4 \%, 14$ per meg and $0.4 \%$, respectively.

CONCLUSIONS: In light of the obtained results, recommendations for the calibration of atmospheric water vapor isotope measurements are presented. The necessity to use dry ambient air as dry air source when running the standards for calibration is pointed out as a pre-requisite for accurate atmospheric water vapor ${ }^{17} \mathrm{O}$-excess and d-excess measurements.

Keywords: laser spectrometry, CRDS, atmospheric water vapor, calibration, ${ }^{17} \mathrm{O}$-excess, d-excess 


\section{Introduction}

Stable isotope ratios of atmospheric water vapor, commonly expressed by $\delta^{2} \mathrm{H}, \delta^{18} \mathrm{O}$, and d-excess $\left[=\delta^{2} \mathrm{H}-8 \cdot \delta^{18} \mathrm{O}\right]$, provide

30 key information on processes in Earth's hydrologic cycle, e.g., cloud formation, precipitation, evaporation and plant transpiration, and can serve as tracers for moisture sources and atmospheric transport patterns (e.g., Pfahl and Wernli, 2008; Wang et al., 2010; Tremoy et al., 2012; Berkelhammer et al., 2013; Aemisegger et al., 2014; Steen-Larsen et al., 2015; Aron et al., 2019; Leroy-Dos Santos et al., 2020). Recent analytical developments enabled the measurement of $\delta^{17} \mathrm{O}$ of atmospheric water vapor in addition to $\delta^{18} \mathrm{O}$, allowing the determination of ${ }^{17} \mathrm{O}$-excess $\left[=\delta^{37} \mathrm{O}-0.528 \cdot \delta^{18} \mathrm{O}\right.$ with $\left.35 \delta^{\prime}=1000 \cdot \ln (\delta / 1000+1)\right]$. Compared to d-excess, the ${ }^{17} \mathrm{O}$-excess parameter is less sensitive to temperature and equilibrium isotope fractionation effects that accompany phase transitions and isotope exchange between different water reservoirs (Barkan and Luz, 2005). The ${ }^{17} \mathrm{O}$-excess is a powerful indicator of water evaporation (Barkan and Luz, 2007; Surma et al., 2015,2018 ) and can serve to identify mixing between evaporated and unevaporated waters, occurring, e.g., due to periodic flooding of lakes in evaporative environments, during groundwater formation, or in plant leaves (Alexandre et al., 2019;

40 Voigt et al., 2021). The ${ }^{17} \mathrm{O}$-excess of precipitation and cryogenically trapped atmospheric water vapor can be used to reconstruct evaporative conditions at ocean sources, identify raindrop re-evaporation and trace continental moisture recycling (Landais et al., 2010, 2012; Uemura et al., 2010; Lin et al., 2013; Steig et al., 2014; Tian et al., 2018, 2021; Uechi and Uemura, 2019; Ranjan et al., 2021; Surma et al., 2021). Specifically, Uemura et al (2010) showed that the ${ }^{17} \mathrm{O}$-excess of atmospheric water vapor above the ocean correlates negatively with relative humidity normalized to sea surface temperature.

45 Uechi and Uemura (2019) demonstrated that this signal is preserved in precipitation in subtropical regions, leading to variability in ${ }^{17} \mathrm{O}$-excess by about 30 per meg. Landais et al. (2010) showed a strong influence of raindrop re-evaporation on ${ }^{17} \mathrm{O}$-excess of African monsoon precipitation in the order of 20-30 per meg during convective activity. Furthermore, Surma et al. (2021) showed that local sublimation of snow in mountainous regions can lead to an increase of the ${ }^{17} \mathrm{O}$-excess of atmospheric water vapor by 60 per meg. While precipitation records and cryogenically trapped vapor samples can provide

50 punctual information, continuous high-resolution measurements of ${ }^{17} \mathrm{O}$-excess and d-excess of atmospheric water vapor may help to resolve large-scale processes in the air mass history that influence the atmospheric water balance (Uemura et al., 2010; Landais et al., 2012; Lin et al., 2013; Ranjan et al., 2021; Surma et al., 2021).

Recently, laser spectroscopic techniques, such as off-axis integrated cavity output spectroscopy (ICOS) and wavelengthscanned cavity ring down spectroscopy (CRDS), enabled direct and continuous isotope measurements of water vapor. Using

55 ICOS, Tian et al. (2016) assessed the accuracy and precision of $\delta^{17} \mathrm{O}, \delta^{18} \mathrm{O}$ and $\delta^{2} \mathrm{H}$ of a continuously vaporized liquid water standard measured at a constant water mixing ratio of 15000 ppmv. However, the implication for ${ }^{17} \mathrm{O}$-excess was not discussed. Using CRDS, Steig et al. (2014) showed that the precision on ${ }^{17} \mathrm{O}$-excess of liquid water continuously vaporized at 20000 ppmv was better than 10 per meg for an integration time of 20 minutes, and thus comparable to precisions obtained using conventional isotope ratio mass spectrometry (IRMS). Brady and Hodell (2021) and Outrequin et al. (2021) presented 60 for the first time continuous CRDS water vapor records of $\delta^{17} \mathrm{O}, \delta^{18} \mathrm{O}, \delta^{2} \mathrm{H},{ }^{17} \mathrm{O}$-excess, and d-excess carried out in laboratory 
chamber experiments. Using an integration time of either 12.5 minutes (Brady and Hodell, 2021) or 80 minutes (Outrequin et al., 2021), a precision of $<10$ per meg in ${ }^{17} \mathrm{O}$-excess was achieved.

While high frequency time series of raw atmospheric water vapor isotope data can be easily obtained using laser spectrometry, the main difficulty in producing robust isotope datasets is related to the calibration procedure (Gkinis et al.,

65 2010; Schmidt et al., 2010; Tremoy et al., 2011; Aemisegger et al., 2012; Steen-Larsen et al., 2013; Bastrikov et al., 2014; Guilpart et al., 2017; Fiorella et al., 2018; Bonne et al., 2019; Weng et al., 2020). Two calibration steps are required. The first step aims to correct for the dependency of the measured isotope composition on the water mixing ratio of the atmosphere (thereafter called "mixing ratio dependency"). Previous studies showed that the mixing ratio dependencies of $\delta^{18} \mathrm{O}, \delta^{2} \mathrm{H}$, and d-excess, which can account for several per mil per $10000 \mathrm{ppmv}$, are generally non-linear and vary with the

70 isotope composition of the vaporized water standard (e.g., Schmidt et al., 2010; Tremoy et al., 2011; Aemisegger et al., 2012; Wen et al., 2012; Bailey et al., 2015; Weng et al., 2020). A few studies suggested that this is also the case for $\delta^{17} \mathrm{O}$ (Steig et al., 2014; Tian et al., 2016). The mixing ratio dependencies of $\delta^{18} \mathrm{O}, \delta^{2} \mathrm{H}$, and d-excess were shown to be instrument-specific, but reproducible over 1-2 years for a specific setup (Weng et al., 2020). The second step involves the VSMOW-SLAP normalization by linear regression computed from the isotope composition of water standards.

75 All calibration techniques require the injection and vaporization of liquid water standards in a carrier gas prior to the analysis. Three principal vaporization methods are in use: 1) Dew-point generator or custom-built bubbler systems are used to produce a saturated water vapor stream by bubbling dry air through a liquid water reservoir (Wang et al., 2009; Wen et al., 2012; Steen-Larsen et al., 2013; Bailey et al., 2015). This water vapor stream is subsequently mixed with dry air to regulate the water mixing ratio. This setup, which involves only partial evaporation of the liquid, comes with the caveat of a changing 80 isotope composition of the water reservoir due to evaporation. The effect of evaporation can be corrected using a Rayleigh distillation model. This, however, requires the accurate determination of the isotope composition of the initial and the residual water as well as precise measurements of temperature and atmospheric pressure over the calibration period (Wang et al., 2009; Aemisegger et al., 2012; Wen et al., 2012); 2) Complete evaporation of the liquid water can be achieved by continuously dripping water in dry air, and thereby producing a water vapor stream with an isotope composition equal to that

85 of the injected water. Syringe pump calibration systems allow to dynamically adjust the water mixing ratio of the water vapor stream by changing the flow rate of either the dry air or the liquid water. These systems include custom-built systems and commercially available units as the standard delivery module (SDM) for CRDS from Picarro Inc. and the water vapor isotope standard source (WVISS) for ICOS from Los-Gatos Research Inc. (e.g., Tremoy et al., 2011; Aemisegger et al., 2012; Steen-Larsen et al., 2013; Bastrikov et al., 2014; Bonne et al., 2014; Casado et al., 2016; Tian et al., 2016; Bréant et 90 al., 2019; Leroy-Dos Santos et al., 2020, 2021). The WVISS unit was used once to measure $\delta^{17} \mathrm{O}$ (Tian et al., 2016). The output of $\delta^{17} \mathrm{O}$ using the SDM is currently not supported by Picarro. However, after software modification, Brady and Hodell (2021) used the SDM to calibrate $\delta^{17} \mathrm{O}, \delta^{18} \mathrm{O}, \delta^{2} \mathrm{H}$ of water vapor measured in an evaporation chamber atmosphere; 3) Complete evaporation of liquid water standards can also be achieved by flash vaporization using the Picarro vaporizer coupled with an autosampler, as in routine analyses of liquid water samples. This system is convenient for atmospheric water 
vapor studies in tropical, subtropical and mid-latitude environments, where the atmospheric water mixing ratio is typically higher than 5000 ppmv (Gupta et al., 2009; Schmidt et al., 2010; Bailey et al., 2013; Delattre et al., 2015). In more arid areas, such as polar regions, syringe pump calibration systems are preferentially used (Steen-Larsen et al., 2013; Bonne et al., 2014; Casado et al., 2016; Bréant et al., 2019; Leroy-Dos Santos et al., 2020).

The type of carrier gas used for the liquid water standard vaporization should be carefully selected. Previous studies have

100 shown that the major chemical components of the atmosphere $\left(\mathrm{N}_{2}, \mathrm{O}_{2}, \mathrm{Ar}, \mathrm{CO}_{2}, \mathrm{CH}_{4}\right)$ interfere with the target absorption peaks of water (Hendry et al., 2011; Gralher et al., 2016; Johnson and Rella, 2017). Consequently, differences in chemical composition, i.e., the matrix, between the carrier gas and the atmosphere impact the calibration of the atmospheric water vapor isotope ratios. This effect is thereafter called the "matrix effect". In previous studies, both synthetic air (e.g., Delattre et al., 2015; Casado et al., 2016; Bonne et al., 2019; Leroy-Dos Santos et al., 2021) and dried ambient air (e.g., Gupta et al.,

105 2009; Steen-Larsen et al., 2013, 2014, 2015; Aemisegger et al., 2014; Bonne et al., 2014; Berkelhammer et al., 2016; Fiorella et al., 2018; Aron et al., 2019) were used when calibrating $\delta^{18} \mathrm{O}, \delta^{2} \mathrm{H}$, and d-excess of atmospheric water vapor, although, on account of a potential matrix effect, it was emphasized that dried ambient air should be preferred (Aemisegger et al., 2012; Brady and Hodell, 2021). When using ambient air as the dry air source, attention was drawn to residual water, resulting from incomplete drying, which mixes with the vaporized liquid water standard and can consequently bias the

110 measured isotope composition, particularly when the analysis is performed at a low water mixing ratio (Tremoy et al., 2011; Aemisegger et al., 2012; Bastrikov et al., 2014; Weng et al., 2020). A correction of this mixing bias is generally difficult (Tremoy et al., 2011; Aemisegger et al., 2012).

Here, we assessed the magnitude of the matrix effect by using synthetic and ambient air as dry air source when analyzing the water standards assigned to calibrate $\delta^{17} \mathrm{O}, \delta^{18} \mathrm{O}, \delta^{2} \mathrm{H},{ }^{17} \mathrm{O}$-excess, and d-excess of atmospheric water vapor by CRDS.

115 Furthermore, the contribution of differences in the $\mathrm{CO}_{2}$ concentration to the matrix effect was evaluated. Additionally, the degree of drying required to obtain accurate calibration results when using ambient air was examined. Precisions obtained for the calibrated isotope data of atmospheric water vapor were quantified. In light of the obtained results, recommendations for the calibration of atmospheric water vapor isotope measurements are presented.

\section{Methods}

\section{$120 \quad 2.1$ Instrumental configuration}

A CRDS (L2140-i, Picarro Inc., USA) combined with an autosampler (A0325, Picarro Inc., USA) and a high-precision vaporizer (A0211, Picarro Inc., USA) was operated at the European Ecotron of Montpellier (France). For the analysis of liquid standards, the water was injected in the vaporizer through a septum-sealed injection port with a $10 \mu 1$ gas-tight syringe (SGE, ref.: 002982, Trajan, Australia). In the vaporizer, the liquid was flash-evaporated at $110^{\circ} \mathrm{C}$ in a dry air stream and then

125 passed to the sample cavity. For the analysis of atmospheric water vapor, ambient air was sampled under the rooftop of the Ecotron building at approximately $3 \mathrm{~m}$ above ground level. The air was pumped through $3 \mathrm{~m}$ of $1 / 8$-inch OD copper tubing 
at a flow rate of $1 \mathrm{~L} / \mathrm{min}$, and then subsampled by the instrument. The tubing was insulated and heated to prevent condensation. A stainless-steel particulate filter with $7 \mu \mathrm{m}$ pore size (Swagelok, USA) was placed at the inlet to avoid suction of insects and particles. All the analyses reported herein were performed in "O17 Dual Liquid/Vapor" mode using

130 "Air" as the carrier gas type.

In laser spectrometry (ICOS, CRDS), the isotope composition of water vapor is determined from its near-infrared absorption spectrum. The absorption spectrum is obtained by tuning the laser wavelength across the absorption line of the target isotopologue $\left({ }^{1} \mathrm{H}_{2}{ }^{16} \mathrm{O},{ }^{1} \mathrm{H}_{2}{ }^{17} \mathrm{O},{ }^{1} \mathrm{H}_{2}{ }^{18} \mathrm{O},{ }^{2} \mathrm{H}^{1} \mathrm{H}^{16} \mathrm{O}\right)$. The operational principle of CRDS, which was used in the present study, is described in detail elsewhere (Crosson, 2008; Steig et al., 2014). In principle, the sample gas is introduced into a high-finesse

135 optical cavity, and then quickly filled with single-frequency laser light. When a threshold level is reached, the laser is turned off and a photodetector measures the exponential decay time of the light intensity in the cavity - expressed as the cavity ring-down time. While older models of Picarro laser analyzers (L2130-i and earlier) calculate the isotope $\operatorname{ratios}\left({ }^{18} \mathrm{O} /{ }^{16} \mathrm{O}\right.$ and ${ }^{2} \mathrm{H} /{ }^{1} \mathrm{H}$ ) based on the amplitude of the absorption peaks, the Picarro L2140-i integrates the absorption over the spectral peaks. Using the integral rather than the height of the absorption peak significantly reduces the mixing ratio dependency of isotope measurements, which mainly results from the effect of pressure broadening on the peak shape (Steig et al., 2014). This, along with accurate measurement and control of the laser's wavelength by the wavelength monitor, as well as precise temperature $\left( \pm 0.005^{\circ} \mathrm{C}\right)$ and pressure $( \pm 0.0002 \mathrm{~atm})$ control in the sample cavity, enables high-precision measurements of $\delta^{17} \mathrm{O}, \delta^{18} \mathrm{O}$, and $\delta^{2} \mathrm{H}$ of water vapor.

\subsection{Liquid standards and dry air sources}

145 Two water standards, namely ICE and TAP, were used (Table 1). Both standards cover a range in $\delta^{18} \mathrm{O}$ from -26.8 to $-8.6 \%$ that is characteristic for atmospheric water vapor in continental mid-latitude environments (e.g., Lee et al., 2007; Aemisegger et al., 2014; Delattre et al., 2015; Salamalikis et al., 2015; Berkelhammer et al., 2016).

Two different dry air sources were used: (1) Synthetic air supplied by a gas cylinder (Alphagaz 2 Air, ref.: P0292L50S2A001, Air Liquide, France); (2) Compressed ambient air dried to three different levels. The synthetic air is

150 a mixture of pure gases with a chemical composition specified by the manufacturer as $\mathrm{N}_{2}=79.1 \mathrm{~mol}-\%, \mathrm{O}_{2}=20.9$ mol- $\%$ and trace amounts of $\mathrm{H}_{2} \mathrm{O}(<0.5 \mathrm{ppm}), \mathrm{CO}_{2}, \mathrm{CO}(<0.1 \mathrm{ppm})$, hydrocarbons $(<0.05 \mathrm{ppm}), \mathrm{NO}_{\mathrm{x}}$ and $\mathrm{SO}_{2}(<0.01 \mathrm{ppm})$. The ambient air was provided by either a stationary oil free rotary screw compressor (CompAir, Ingersoll Rand Inc., France) or a lubricated mobile air compressor (Mod.: MONTECARLO FC2, ABAC air compressors, Italy). The latter was used in view of future field measurements. Downstream of the stationary compressor, large capacity and self-regenerating molecular sieve

155 adsorbents for $\mathrm{CO}_{2}$ and $\mathrm{H}_{2} \mathrm{O}$ and an activated charcoal filter were installed. The $\mathrm{CO}_{2}$ concentration of the provided air was less than 2 ppmv, as verified periodically using a Picarro G2101-i instrument. The air supplied by the mobile compressor, which was only equipped with an activated charcoal filter, was assumed to have a chemical composition similar to that of the ambient atmosphere. Two different drying systems were used: (a) Two regenerative drierite units combined with one magnesium perchlorate column $(10 \mathrm{~cm})$, and (b) a stainless-steel double coil $(\varnothing \sim 7 \mathrm{~cm})$ immersed in dry ice $\left(-78^{\circ} \mathrm{C}\right)$. The 
160 water content in the air provided from one or the other compressor connected in series with (a) and (b) was less than 40 ppmv, as indicated by the laser spectrometer. As a similar water background was observed when using synthetic air, the real water content in the dry air provided by this setup is likely $<0.5$ ppmv. The different dry air source configurations and their residual water contents are summarized in Table 2.

\subsection{Measurement protocols for water standard analyses}

165 The impact of residual water in the dry air source was assessed by comparing water standard measurements using ambient air with the different drying setups $\left(\mathrm{AA}_{\text {stat }}-40_{\mathrm{CO} 2 \text {-free, }} \mathrm{AA}_{\text {stat }}-100_{\mathrm{CO} 2 \text {-free }}\right.$ or $\left.\mathrm{AA}_{\text {stat }}-300_{\mathrm{CO} 2 \text {-free}}\right)$ (Table 2). Measurements with each of these dry air sources started with 10 injections of $1.7 \mu \mathrm{L}$ of the respective water standard for instrument conditioning, followed by 162 injections with the injection volume set to either $0.5 \mu \mathrm{L}$ (i.e., a water mixing ratio of 6000 ppmv) or $1.9 \mu \mathrm{L}$ (i.e., a water mixing ratio of $25000 \mathrm{ppmv}$ ). When processing the data, a memory effect that lasted longer than 100 injections

170 was detected for measurements carried out at 6000 ppmv. To account for this memory effect, we discarded the first 108 injections. The remaining 54 injections were averaged over groups of 6 injections.

The mixing ratio dependencies of $\delta^{17} \mathrm{O}, \delta^{18} \mathrm{O}, \delta^{2} \mathrm{H},{ }^{17} \mathrm{O}$-excess and d-excess were examined for ICE and TAP using synthetic air (SA-40) and dry ambient air ( $\left.\mathrm{AA}_{\mathrm{port}}-40\right)$. The injection volume was regulated over a total of 10 steps, corresponding to water mixing ratios varying from 2000 to 30000 ppmv. Sequences were measured alternatingly in ascending and descending

175 order of the injection volume to identify potential hysteresis effects. The evaluation of the mixing ratio dependencies performed using SA-40 started with 16 injections of $1.7 \mu \mathrm{L}$ of the respective water standard for instrument conditioning. Then, three sequences were run, starting in ascending order of the injection volume. At each injection volume, 16 injections were carried out. When processing the data, the first 4 injections at each injection volume were discarded and the remaining 12 injections were averaged over groups of 6 injections. The data obtained from the first (ascending) sequence significantly deviate from the data obtained in the two following sequences. We attributed this to the fact that the number of pre-injections may have been insufficient to fully remove the memory effect. Therefore, the first sequence for each working standard was discarded. In consideration of a long-lasting memory effect at low water mixing ratios, measurements using $\mathrm{AA}_{\text {port }}-40$ started with 30 injections of $1.7 \mu \mathrm{L}$ of the respective water standard for instrument conditioning. Then, two sequences were run, starting in descending order of the injection volume. At each injection volume, 10 injections were carried out. When

185 processing the data, the first 4 injections at each injection volume were discarded and the remaining 6 injections were averaged.

\subsection{Procedure for calibrating the atmospheric water vapor isotope composition}

The procedure applied to calibrate the raw atmospheric water vapor isotope dataset obtained from the Ecotron, using ICE and TAP analyzed with (i) SA-40 and (ii) $\mathrm{AA}_{\text {port }}-40$, was divided into three steps:

190 1) The mixing ratio dependency functions for $\delta^{17} \mathrm{O}, \delta^{18} \mathrm{O}, \delta^{2} \mathrm{H}$ of ICE and TAP were determined. Following Weng et al. (2020), we used a function of the form $f(x)=a / x+b x+c$, which was fitted through the isotope composition of 
the water standard obtained at different water mixing ratios between 2000 and 30000 ppmv. The coefficients a, b, and $\mathrm{c}$ denote the fitting coefficients and $\mathrm{x}$ represents the water mixing ratio of the analysis.

2) The mixing ratio dependency of raw water vapor isotope measurements was accounted for by correcting the isotope composition of the water standards to the atmospheric water mixing ratio. This approach was also used by Bonne et al. (2014). Other studies corrected the measured atmospheric water vapor composition to the water mixing ratio of the water standards (e.g., Tremoy et al., 2011; Aemisegger et al., 2012; Steen-Larsen et al., 2013; Bastrikov et al., 2014; Guilpart et al., 2017; Fiorella et al., 2018; Bonne et al., 2019; Weng et al., 2020). Weng et al. (2020) showed that both approaches give similar results, when variations in the isotope composition of the atmospheric water vapor are relatively small.

3) The raw atmospheric water vapor isotope data was normalized to the VSMOW-SLAP scale using the mixing ratiocorrected raw isotope composition obtained for ICE and TAP (IAEA, 2007).

\subsection{Precision assessment of calibrated atmospheric water vapor data}

The precision of the calibrated atmospheric water vapor isotope composition was evaluated using a Monte Carlo simulation, accounting for the precision of the raw liquid water standard and atmospheric water vapor measurements, and all the steps of the calibration procedure.

The precision of raw $\delta^{17} \mathrm{O}, \delta^{18} \mathrm{O}, \delta^{2} \mathrm{H},{ }^{17} \mathrm{O}$-excess and d-excess values of atmospheric water vapor was inferred from an Allan deviation analysis of a water vapor source with stable isotope composition supplied by a dew-point generator using $\mathrm{AA}_{\text {stat }}-300_{\mathrm{CO} 2 \text {-free }}$ as the carrier gas. Over the 24-hours analytical period, the water mixing ratio was $20250 \pm 550 \mathrm{ppmv}$. The

210 Allan deviation $\sigma_{\mathrm{A}}$, which can be interpreted as the precision of the raw water vapor isotope data integrated over the integration time $\tau$, is calculated as the square root of the Allan variance $\sigma_{\mathrm{A}}{ }^{2}$, defined as:

$$
\sigma_{A}^{2}(\tau)=\frac{1}{2 n} \sum_{i=1}^{n}\left[y_{i+1}(\tau)-y_{i}(\tau)\right]^{2}
$$

where $y_{i}$ and $y_{i+1}$ are the average values of the measurements in two consecutive averaging intervals $i$ and $n$ is the total number of averaging intervals (Werle, 2011). In regard of the precision required for the objective of the study, the Allan

215 deviation analyses is used to estimate the optimum integration time for calibrated high-resolution atmospheric water vapor isotope data.

The precision of raw $\delta^{17} \mathrm{O}, \delta^{18} \mathrm{O}, \delta^{2} \mathrm{H},{ }^{17} \mathrm{O}$-excess and d-excess of the water standards was calculated from the SD of the mean of 9 groups of 6 injections (corresponding to 8-hours measurement time) at water mixing ratios of 6000 ppmv and 25000 ppmv and using $\mathrm{AA}_{\text {stat }}-40 \mathrm{CO}-$-free.

220 The precision of the calibrated atmospheric water vapor isotope composition is estimated from the SD of the mean values of the VSMOW-SLAP normalized $\delta^{17} \mathrm{O}, \delta^{18} \mathrm{O}, \delta^{2} \mathrm{H},{ }^{17} \mathrm{O}$-excess and d-excess of atmospheric water vapor obtained from 100000 calibration simulations. In each simulation, random normally distributed isotope values with the mean and the SD of 
the raw water standard and water vapor measurements as well as the VSMOW-SLAP normalized values of the water standards are generated, and the calibration steps described in Section 2.4 are carried out. As input parameters, the raw isotope composition of atmospheric water vapor was set to the mean raw $\delta^{17} \mathrm{O}, \delta^{18} \mathrm{O}$ and $\delta^{2} \mathrm{H}$ values of the atmospheric water vapor dataset obtained at Ecotron $(-7.346 \%,-14.703 \%$, and $-86.33 \%$, respectively). For the raw isotope values of ICE and TAP, the mean and $\mathrm{SD}$ of the isotope compositions measured at different water mixing ratios obtained using $\mathrm{AA}_{\text {port }}-40$ were used.

\section{Results}

\subsection{Impact of the dry air source on liquid water analyses}

Figure 1 shows that the raw isotope data obtained using SA-40 and $\mathrm{AA}_{\text {port- }} 40$ differ strongly, both at water mixing ratios of 6000 and 25000 ppmv. The isotope offset between these two gas configurations is similar for both water standards, and particularly important for ${ }^{17} \mathrm{O}$-excess and d-excess. At a water mixing ratio of 6000 ppmv, values of $\delta^{17} \mathrm{O}, \delta^{18} \mathrm{O}, \delta^{2} \mathrm{H}$, ${ }^{17} \mathrm{O}$-excess and d-excess obtained using SA-40 and $\mathrm{AA}_{\text {port- }} 40$ differ by $-0.61 \pm 0.04 \%,-0.74 \pm 0.07 \%$, $+1.5 \pm 0.4 \%$, $235217 \pm 2$ per meg, and $+7.4 \pm 0.1 \%$, respectively (Table 3). At $25000 \mathrm{ppmv}$, the isotope differences between these two configurations are slightly smaller, yielding $-0.58 \pm 0.07 \%$, $-0.71 \pm 0.14 \%,+0.8 \pm 0.9 \%,-202 \pm 4$ per meg, and $+6.5 \pm 0.2 \%$ for $\delta^{17} \mathrm{O}, \delta^{18} \mathrm{O}, \delta^{2} \mathrm{H},{ }^{17} \mathrm{O}$-excess, and d-excess, respectively (Table 3 ). These results indicate the occurrence of different interferences on the adsorption spectra when using SA-40 and $\mathrm{AA}_{\text {port }}-40$, and imply that a significant matrix effect can be expected when using the synthetic air type and instrumental setup used in this study.

240 Figure 1 further demonstrates that differences in $\mathrm{CO}_{2}$ concentrations between the dry air source and the atmosphere can only account for a small part of this matrix effect. Isotope data obtained using $\mathrm{AA}_{\text {port }}-40$ and $\mathrm{AA}_{\text {stat }}-40_{\mathrm{CO} 2 \text {-free }}$ show slight differences, which are however lower than the instrument drift specified by the manufacturer, i.e., $<0.2 \%$ for $\delta^{17} \mathrm{O}$ and $\delta^{18} \mathrm{O},<0.8 \%$ for $\delta^{2} \mathrm{H}$, and $<200$ per meg for ${ }^{17} \mathrm{O}$-excess (Table 3 ), and substantially smaller than the differences observed between $\mathrm{AA}_{\text {port }}-40$ and SA-40.

245 Figure 2 illustrates that the effect of residual water in the ambient air resulting from incomplete drying on isotope data differs from that of the matrix effect. The isotope composition of ICE and TAP obtained at a water mixing ratio of $6000 \mathrm{ppmv}$ using ambient air with the different drying setups $\left(\mathrm{AA}_{\text {stat }}-40_{\mathrm{CO} 2 \text {-free, }} \mathrm{AA}_{\text {stat }}-100_{\mathrm{CO} 2-\text { free, }} \mathrm{AA}_{\mathrm{stat}}-300_{\mathrm{CO} 2 \text {-free}}\right)$ changes linearly with increasing residual water content. The impact of residual water on the measured isotope composition is different for both water standards. For TAP, an increase of the residual water content leads to a decrease in $\delta^{17} \mathrm{O}, \delta^{18} \mathrm{O}$ and $\delta^{2} \mathrm{H}$, whereas the inverse is observed for ICE (Table 3). This inverse relation indicates that the admixed residual water vapor has an intermediate isotope composition. Values of d-excess increase with the residual water content for both water standards, whereas no systematic change is observed for ${ }^{17} \mathrm{O}$-excess. Residual water in the dry air source has no impact on the raw isotope composition at a water mixing ratio of $25000 \mathrm{ppmv}$ (data not shown). 


\subsection{Impact of the dry air source on the mixing ratio dependencies}

255 Figure 3 shows the mixing ratio dependencies of the mean raw values of $\delta^{17} \mathrm{O}, \delta^{18} \mathrm{O}, \delta^{2} \mathrm{H}$, ${ }^{17} \mathrm{O}$-excess, and d-excess obtained for ICE and TAP using SA-40 and $\mathrm{AA}_{\text {port }}-40$. The results obtained from ascending and descending measurement sequences are in agreement for all isotope parameters, indicating that memory effects of previous injections and potential hysteresis effects are not substantial. To ensure comparison between both water standards and dry air sources, the isotope compositions were normalized to a reference water mixing ratio of $10000 \mathrm{ppmv}$ by linear interpolation between the closest measurements

260 above and below $10000 \mathrm{ppmv}$ (cf. Weng et al., 2020). For unidentified reasons, $\delta^{17} \mathrm{O}, \delta^{18} \mathrm{O}$, and $\delta^{2} \mathrm{H}$ values obtained for ICE at $\sim 13000$ ppmv are higher than expected from the general trend. These outliers were not considered when normalizing to the reference water mixing ratio and determining the mixing ratio dependency functions.

The mixing ratio dependencies of $\delta^{17} \mathrm{O}, \delta^{18} \mathrm{O}$, and $\delta^{2} \mathrm{H}$ are non-linear and vary with the isotope composition of the water standard, as shown for $\delta^{18} \mathrm{O}$ and $\delta^{2} \mathrm{H}$ in previous studies (Schmidt et al., 2010; Tremoy et al., 2011; Aemisegger et al., 2012;

265 Wen et al., 2012; Bailey et al., 2015; Weng et al., 2020). The isotope composition of the water standard has however a negligible effect on the mixing ratio dependencies of ${ }^{17} \mathrm{O}$-excess and d-excess for our instrument.

The mixing ratio dependencies of $\delta^{17} \mathrm{O}, \delta^{18} \mathrm{O}$, and $\delta^{2} \mathrm{H},{ }^{17} \mathrm{O}$-excess and d-excess obtained using SA-40 and $\mathrm{AA}_{\text {port- }}-40$ are similar, indicating that the matrix effect expected when using SA-40 is not significantly influenced by the water mixing ratio of the analyzed atmospheric water vapor. This further supports the assumption that using the $\mathrm{AA}_{\text {port }}-40$ dry air source configuration has a similar water background than the synthetic air $(<0.5 \mathrm{ppmv})$, as residual water would add a bias to the mixing ratio dependency that becomes increasingly important towards lower mixing ratios. For TAP, a slight isotope offset between SA-40 and $\mathrm{AA}_{\text {port- }} 40$ is obtained for water mixing ratios $<5000$ ppmv, which however remains within uncertainty. For ICE, the mixing ratio dependencies of $\delta^{2} \mathrm{H}$ and d-excess obtained using SA-40 and $\mathrm{AA}_{\text {port }}-40$ agree within error. In contrast, those of $\delta^{17} \mathrm{O}, \delta^{18} \mathrm{O}$, and ${ }^{17} \mathrm{O}$-excess are slightly rotated, leading to isotope differences of about $0.10 \%, 0.13 \%$ and 45 per meg at the lower and the upper limit of the mixing ratio dependency.

\subsection{Precision of liquid water and atmospheric water vapor isotope data}

The SD of the mean raw values of $\delta^{17} \mathrm{O}, \delta^{18} \mathrm{O}, \delta^{2} \mathrm{H},{ }^{17} \mathrm{O}$-excess, and d-excess of ICE and TAP obtained using AA $\mathrm{A}_{\text {stat }}-40_{\mathrm{CO}-\text {-free }}$ fall generally within the precision guaranteed by the manufacturer $\left(0.025 \%\right.$ for $\delta^{17} \mathrm{O}$ and $\delta^{18} \mathrm{O}, 0.1 \%$ for $\delta^{2} \mathrm{H}$, and 15 per meg for ${ }^{17} \mathrm{O}$-excess) (Table 3 ). The obtained precisions are similar for both water standards. No difference in precision is observed between analysis performed at water mixing ratios of 6000 and $25000 \mathrm{ppmv}$.

Figure 4 shows the Allan deviations for $\delta^{17} \mathrm{O}, \delta^{18} \mathrm{O}, \delta^{2} \mathrm{H},{ }^{17} \mathrm{O}$-excess, and d-excess of a stable water vapor stream supplied by the dew-point generator. The obtained Allan deviations are broadly consistent with results of previous studies that used a Picarro L2140-i instrument (Steig et al., 2014; Schauer et al., 2016; Brady and Hodell, 2021). The Allan deviations decrease for all isotope values, reaching minimum values of $0.006 \% 0,0.007 \%$, $0.04 \%, 5$ per meg and $0.09 \%$ for $\delta^{17} \mathrm{O}, \delta^{18} \mathrm{O}, \delta^{2} \mathrm{H}$, ${ }^{17} \mathrm{O}$-excess, and d-excess, respectively, between 2800 and 4500 seconds. In the following, we use an integration time of 
12 minutes, which allows to achieve a precision of better than 10 per meg for ${ }^{17} \mathrm{O}$-excess. The Allan deviations for $\delta^{17} \mathrm{O}$, $\delta^{18} \mathrm{O}, \delta^{2} \mathrm{H}$, and d-excess for this integration time are $0.014 \%, 0.013 \%, 0.06 \%$ and $0.14 \%$, respectively.

For atmospheric water mixing ratios between 5000 and 25000 ppmv and using an integration time of 12 minutes, the Monte Carlo simulation indicates precisions of $0.02 \%, 0.03 \%, 0.4 \%$, 14 per meg and $0.4 \%$ for the VSMOW-SLAP normalized

$290 \delta^{17} \mathrm{O}, \delta^{18} \mathrm{O}, \delta^{2} \mathrm{H},{ }^{17} \mathrm{O}$-excess and d-excess values of atmospheric water vapor, respectively. Increasing uncertainty of the mixing ratio dependency functions towards their upper and lower limits leads to a decrease in precision of the calibrated atmospheric water vapor isotope composition in particular at low water mixing ratios. At a water mixing ratio of $2000 \mathrm{ppmv}$, the precision of $\delta^{17} \mathrm{O}, \delta^{18} \mathrm{O}, \delta^{2} \mathrm{H},{ }^{17} \mathrm{O}$-excess and d-excess is $0.03 \%$, $0.07 \%, 0.5 \%$, 33 per meg and $0.7 \%$, respectively. For water mixing ratios higher than 25000 ppmv, the precision of ${ }^{17} \mathrm{O}$-excess decreases slightly, yielding 18 per meg at a

295 water mixing ratio of 30000 ppmv, while no significant precision change is observed for $\delta^{17} \mathrm{O}, \delta^{18} \mathrm{O}, \delta^{2} \mathrm{H}$, and $\mathrm{d}$-excess, respectively. The precisions obtained from this Monte Carlo simulation represent the optimum precisions that can be achieved if the isotope composition of atmospheric water vapor is stable over the integration time, which is a reasonable assumption for the 12-minutes integration time used in this study.

\subsection{Impact of the dry air source on calibrated atmospheric water vapor isotope data}

300 Figure 5 shows the 12-minutes integrated isotope composition of atmospheric water vapor measured at the Ecotron. Over the 48-hours measurement period, the atmospheric water mixing ratio showed little variation between 11500 and 15100 ppmv, while $\delta^{17} \mathrm{O}$ varied by $1.1 \%$, $\delta^{18} \mathrm{O}$ by $2.1 \%$, $\delta^{2} \mathrm{H}$ by $9.0 \%$, ${ }^{17} \mathrm{O}$-excess by 65 per meg, and d-excess by $9.8 \%$. Calibration of this dataset using water standards analyzed with $\mathrm{AA}_{\text {port }}-40$ gave $\delta^{17} \mathrm{O}, \delta^{18} \mathrm{O}, \delta^{2} \mathrm{H},{ }^{17} \mathrm{O}$-excess and d-excess values ranging from -7.9 to $-6.8 \%$, from -15.0 to $-12.9 \%$, from -99.4 to $-90.4 \%$, from -9 to 56 per meg, and from 11.1 to $20.9 \%$,

305 respectively. Calibration using water standards analyzed with SA-40 resulted in $\delta^{17} \mathrm{O}, \delta^{18} \mathrm{O}$ and ${ }^{17} \mathrm{O}$-excess value that are $0.6 \%, 0.7 \%$ and more than 217 per meg higher, whereas $\delta^{2} \mathrm{H}$ and d-excess are about $1.5 \%$ and $7.3 \%$ lower. This matrix effect is, as expected, similar to the difference in raw liquid water isotope data observed between $\mathrm{AA}_{\text {port }}-40$ and SA-40 (cf. Sect. 3.1 and Fig. 1).

\section{Discussion}

\section{$310 \quad$ 4.1 Magnitude and origin of the matrix effect}

The difference observed between the liquid water isotope data obtained using synthetic and dry ambient air (Fig. 1) reflects the magnitude of the matrix effect. As the magnitude of the matrix effect is similar for $\delta^{17} \mathrm{O}$ and $\delta^{18} \mathrm{O}$, it has a huge impact on ${ }^{17} \mathrm{O}$-excess. Values of $\delta^{18} \mathrm{O}$ and $\delta^{2} \mathrm{H}$ are affected in opposite ways, resulting in a considerable influence on the d-excess. An effect of water contamination, resulting from incomplete drying of the ambient air or post-drying leakage of ambient air can

315 be ruled out, as this residual water would impact the two water standards in an opposite way (Fig. 2). In contrast, the direction and the magnitude of the matrix effect observed between synthetic air and dry ambient air is similar for the two 
investigated water standards (Fig. 1). In addition, the matrix effect is also observed at a water mixing ratio of $25000 \mathrm{ppmv}$, where traces of residual water in the dry air source have no impact on the measured isotope data. A significant effect of leftover of water from previous injections, i.e., a memory effect, is also unlikely, as a high number of pre-injections was performed to largely remove the matrix effect and no significant trend of the measured isotope values is observed over time. Moreover, the memory effect has generally no impact on ${ }^{17} \mathrm{O}$-excess (Vallet-Coulomb et al., 2021), excluding any contribution to the matrix effect observed for ${ }^{17} \mathrm{O}$-excess. Further, our data gives no indication for any isotope effects associated to the autosampler injection system, e.g., out-of-equilibrium effects caused by adsorption on surfaces and diffusion, that may have contributed to the observed matrix effect. Brady and Hodell (2021), who used the SDM for the calibration of $\delta^{17} \mathrm{O}, \delta^{18} \mathrm{O}$, and $\delta^{2} \mathrm{H}$ chamber atmospheric water vapor, also emphasized the importance of the identity of the gas matrix for the liquid and water vapor measurements, indicating that a similar matrix effect is likely obtained when other injection systems, e.g., the SDM, are used.

Reasonable calibrated ${ }^{17} \mathrm{O}$-excess values of atmospheric water vapor are obtained when dry ambient air (AAport-40) was used as the dry air source (cf. Sect. 3.5), indicating that the observed matrix effect is not related to the removal of gas trace amounts during the drying procedure, but rather the result of trace gases in the atmosphere, such as carbon dioxide, argon, methane and other hydrocarbons or volatile organic compounds, that are not present in the synthetic air type used in this study (Brand et al., 2009; Hendry et al., 2011; Gralher et al., 2016; Johnson and Rella, 2017; Nehemy et al., 2019; Millar et al., 2021). Gralher et al. (2016) showed that changes in the mixing ratios of $\mathrm{N}_{2} / \mathrm{CO}_{2}$ or $\mathrm{CO}_{2} / \mathrm{O}_{2}$ can significantly influence the laser-spectroscopic isotope analysis using a Picarro L2120-i. However, our results show that the difference in the $\mathrm{CO}_{2}$ concentration between the synthetic air and the atmosphere can only account for a small part of the observed matrix effect (Fig. 1), indicating the interference of other molecules with the water absorption spectra. Johnson and Rella (2017) demonstrated that the presence of $\mathrm{Ar}$ in the carrier gas could bias $\delta^{18} \mathrm{O}$ values by $-0.57 \pm 0.001 \% \mathrm{Ar}-\%^{-1}$, while values of $\delta^{2} \mathrm{H}$ were affected inversely by $0.42 \pm 0.004 \% \mathrm{Ar}-\%^{-1}$. Using a dry air source with an atmospheric Ar concentration of $0.93 \%$ (Berner and Berner, 2012) would imply an offset in d-excess of about $4.6 \%$ relative to an Ar-free atmosphere,

340 which is of opposite direction than the matrix effect observed in our study when using argon-free synthetic air (SA-40) to calibrate atmospheric water vapor data. However, the results from the two studies are not directly comparable, as the spectroscopy of the Picarro L2120-i analyzer used by Johnson and Rella (2017), differs from that of the Picarro L2140-i analyzer used here. A contribution of argon to the here observed matrix effect can therefore not be excluded. Methane, which constitutes more than $2 \mathrm{ppm}$ in the modern atmosphere, can additionally influence the measured $\delta^{18} \mathrm{O}$ and $\delta^{2} \mathrm{H}$ values, as

345 shown by Hendry et al. (2011). However, a correction algorithm has been implemented in the Picarro software application, so that a contribution of methane to the here observed matrix effect should be principally excluded. Nevertheless, the contribution of other hydrocarbons may be also substantial. Nehemy et al. (2019) presented ICOS analysis of $\delta^{17} \mathrm{O}, \delta^{18} \mathrm{O}$ and $\delta^{2} \mathrm{H}$ of methanol and ethanol solutions, which demonstrated that the ${ }^{17} \mathrm{O}$-excess is highly sensitive to the presence of organic compounds. The hydroxyl groups of these alcohols absorb near-infrared waves in the same region as water and cause therefore spectral interferences (Hendry et al., 2011). Millar et al. (2021) showed that a change in $0.01 \%$ methanol can bias 
the ${ }^{17} \mathrm{O}$-excess by $>1 \%$ and d-excess by $>10 \%$. Natural atmospheric levels of methanol, which vary from hundreds of parts per trillion in the upper troposphere to tens of parts per billion near surface grounds (e.g., Singh et al., 2004; Bousquet et al., 2006; Schade and Goldstein, 2006; Hu et al., 2011), can thus have a substantial impact on the measured values of the secondary isotope parameters. It is likely that other organic compounds, hydrocarbons and trace gases also interfere with the

355 CRDS absorption spectra. The accurate determination of the interfering molecules is however complex and beyond the scope of this study. Moreover, the content of hydrocarbons and organic compounds in the atmosphere may vary over time due to changes in biological production and consumption rates, but also anthropogenic emissions (e.g., Bousquet et al., 2006; Williams and Koppmann, 2007). An accurate correction is further challenged by the high sensitivity of ${ }^{17} \mathrm{O}$-excess to the matrix effect ( $>200$ per meg) along with the high precision measurements required to resolve the small natural variations of

${ }^{17} \mathrm{O}$-excess $(<10$ per meg). The most effective way to avoid any potential bias due to a matrix effect and circumvent loss of precision due to the application of a correction algorithm is the use of dry ambient air when calibrating atmospheric water vapor isotope data.

\subsection{Implications for the calibration of atmospheric water vapor isotope data in previous and future studies}

As previously described, a number of recent studies indicated that incomplete drying of ambient air can lead to mixing

365 effects between the vaporized sample and residual water in the dry air source, causing an isotope bias (Tremoy et al., 2011; Bastrikov et al., 2014; Weng et al., 2020). Our results confirm this effect and indicate that complete drying of ambient air is of particular importance for water standard analysis at low water mixing ratios as the quantification of this effect using mass balance is challenged by the accurate determination of the residual water content and its isotope composition. The latter is expected to be variable and affected by the different drying reagents used. Since the matrix effect appears to be independent of the water mixing ratio (Fig. 3), the use of synthetic air may be convenient when assessing the mixing ratio dependency, if complete drying of ambient air is not feasible. Similar conclusions were drawn by Weng et al. (2020), who found the mixing ratio dependencies of $\delta^{18} \mathrm{O}, \delta^{2} \mathrm{H}$ and d-excess obtained using synthetic air and $\mathrm{N}_{2}$ in good agreement. This approach was once considered by Bastrikov et al. (2014), who used synthetic air to determine the mixing ratio dependencies of $\delta^{18} \mathrm{O}$ and $\delta^{2} \mathrm{H}$ for water mixing ratios lower than 4000 ppmv. However, for regular water standard analysis assigned to VSMOW-SLAP

375 scaling of atmospheric water vapor data, the use of dry ambient air is essential. The degree of drying required for these analyses depends on the selected reference water mixing ratio, which should be in the mid-range of the atmospheric water mixing ratios observed at the study site. We showed that for analyses at water mixing ratios of $6000 \mathrm{ppmv}$ and lower, the complete drying, e.g., using a cold trap system, is inevitable. Care should be taken that the chemical composition of the ambient air is not modified by the drying procedure, e.g., due to absorption of molecules by molecular sieves or freezing of 380 gases in the cold trap. Reasonable ${ }^{17} \mathrm{O}$-excess values of atmospheric water vapor obtained when using dry ambient air in our setup indicate that a removal of gas trace amounts during the drying procedure, if any, had no significant influence on the isotope data. 
When analyzing the water standards, one should consider a carry-over of the isotope signal of the previous sample on the current measurement, i.e., a memory effect. In our calibration experiments, we observed that the memory effect can last over more than 100 injections at a water mixing ratio of $6000 \mathrm{ppmv}$ indicating a longer persistence of the memory effect at low water mixing ratios. To assess the magnitude of the memory effect, we determined the memory effect factors for water standard analyses performed at water mixing ratios of 10000 ppmv and 20000 ppmv following Vallet-Coulomb et al. (2021). Based on these results, we defined thresholds so that the impact of the memory effect on the measured isotope composition is lower than the precision of the analysis, i.e., $<0.025 \%$ for $\delta^{17} \mathrm{O}$ and $\delta^{18} \mathrm{O}$, and $<0.1 \%$ for $\delta^{2} \mathrm{H}$. If the $\delta^{18} \mathrm{O}$ of two water standards differ by about $15 \%$ (here ICE and TAP), at least 20 pre-injections at a water mixing ratio of 20000 ppmv are required. When analyzing water standards that differ more strongly in isotope composition or when the analysis is performed at lower water mixing ratios, the number of pre-injections should be further increased.

Previously published data of $\delta^{18} \mathrm{O}, \delta^{2} \mathrm{H}$ and d-excess of atmospheric water vapor measured by laser spectrometry using synthetic air for the calibration (Delattre et al., 2015; Casado et al., 2016; Bonne et al., 2019; Leroy-Dos Santos et al., 2021),

395 might be biased by a matrix effect. Delattre et al. (2015) used a Picarro L1102-i to study atmospheric water vapor isotope variability over a Mediterranean coastal wetland, using synthetic air for the calibration. Over a 1-month period, hourlyaverage $\delta^{18} \mathrm{O}$ values ranging from -19.2 to $-9.7 \%$ and d-excess values ranging from 7.8 to $31.2 \%$ were observed, with atmospheric water mixing ratios varying between 9000 and 28000 ppmv. The d-excess values were 11 to $13 \%$ higher than expected from isotope equilibrium between atmospheric vapor and simultaneously sampled precipitation (Delattre et al.,

400 2015). However, a relation of this discrepancy to a matrix effect as observed in our study is unlikely. A matrix effect would lead to an underestimation of the d-excess values in atmospheric water vapor by about $7 \%$, increasing the discrepancy between the atmospheric water vapor and the precipitation data. Bonne et al. (2019) monitored atmospheric water vapor above the Atlantic Ocean from tropical to polar regions using a Picarro L2140-i and synthetic air as carrier gas for the calibration. Their measurements covered a wide range in atmospheric water mixing ratios from 1000 to $30000 \mathrm{ppmv}$ and $405 \delta^{18} \mathrm{O}$ values from -40 to $-10 \%$. Observed values of d-excess varied generally between -10 and $+10 \%$ and range within values obtained from cryogenically trapped atmospheric water vapor sampled above the ocean (Pfahl and Wernli, 2008; Uemura et al., 2008), indicating that the magnitude of a possible matrix effect is not substantial. Casado et al. (2016) and Leroy-Dos Santos et al. (2021) used a Picarro L2130-i for atmospheric water vapor analyses in East Antarctica. Synthetic air was used as the carrier gas for the calibration to prevent any bias due to incomplete drying of ambient air, which is of 410 particular importance at the extremely low atmospheric water mixing ratios of typically $<1000$ ppmv observed in polar areas. These conditions also challenge a precise calibration, in particular the correction for the mixing ratio dependency, leading to higher uncertainty of the calibrated atmospheric water vapor isotope data. Directly measured $\delta^{18} \mathrm{O}$ values of atmospheric water vapor were about $1 \%$ higher than those obtained for simultaneously cryogenically trapped atmospheric water vapor samples, while d-excess values were about $3 \%$ lower, but both differences were lower than the measurement 415 uncertainties (Casado et al., 2016). There is a number of other studies that do not provide specific information on the dry air source used (e.g., Bréant et al., 2019; Leroy-Dos Santos et al., 2020). However, no systematic offset due to a significant 
matrix effect, can be observed in any of these studies. Notably, direct transfer of the matrix effect observed in our study to data obtained in previous studies is not straightforward as it depends on the targeted wavelengths and peak integration algorithms used in the different models of CRDS instruments, the chemical composition of the atmosphere, especially its volatile organic compound content, and the chemical composition of the synthetic air. It is therefore difficult to evaluate whether and to what extent previously published isotope data of atmospheric water vapor are influenced by a matrix effect. The results of our comparison show that if accuracy is sought in the isotope analysis of atmospheric water vapor by laser spectrometry, a potential matrix effect must be considered. The high sensitivity of the ${ }^{17} \mathrm{O}$-excess to this matrix effect makes it essential to use dry ambient air as the dry air source for the calibration of atmospheric water vapor isotope data.

\section{Conclusion}

Our experiments demonstrated the presence of a matrix effect when using synthetic air as the dry air source for water standard analyses assigned to calibrate atmospheric water vapor isotope measurements. We showed that the ${ }^{17} \mathrm{O}-\mathrm{excess}$ of calibrated atmospheric water vapor can be overestimated by more than 200 per meg, while d-excess can be underestimated by more than $7 \%$. This matrix effect is likely related to spectroscopic effects in the instrument caused by argon,

430 hydrocarbons or volatile organic compounds in the atmosphere. Notably, this matrix effect varies only slightly with the water mixing ratio and has, thus, a negligible effect on the mixing ratio dependency of CRDS isotope measurements. However, due to its large impact on the absolute measured isotope values, we emphasize the importance of using dried ambient air as the dry air source for water standard analyses for VSMOW-SLAP normalization of atmospheric water vapor isotope measurements.

435 The calibration protocol presented for $\delta^{17} \mathrm{O}, \delta^{18} \mathrm{O}, \delta^{2} \mathrm{H},{ }^{17} \mathrm{O}$-excess and d-excess measurements of atmospheric water vapor using CRDS allows to achieve a precision of $0.02 \%$ for $\delta^{17} \mathrm{O}, 0.03 \%$ for $\delta^{18} \mathrm{O}, 0.4 \%$ for $\delta^{2} \mathrm{H}, 14$ per meg for ${ }^{17} \mathrm{O}$-excess, and $0.4 \%$ for d-excess, for an integration time of 12 minutes and for water mixing ratios between 5000 to 25000 ppmv. The major aspects for an accurate calibration of laser spectrometric isotope measurements of $\delta^{17} \mathrm{O}, \delta^{18} \mathrm{O}, \delta^{2} \mathrm{H},{ }^{17} \mathrm{O}$-excess and d-excess of atmospheric water vapor in natural environments can be summarized as follows:

1) Ambient air should be used as the dry air source for water standard analysis to avoid any potential matrix effect. Complete drying of ambient air is required for analyses at low water mixing ratios $(<6000 \mathrm{ppmv})$, which is achievable using a cold trap system or a combination of different drying units. If complete drying of ambient air is not feasible at the field site, synthetic air may be used when assessing the mixing ratio dependency. However, for regular water standard analysis dedicated to VSMOW-SLAP scaling, the use of dry ambient air is essential.

2) The mixing ratio dependency functions for $\delta^{17} \mathrm{O}, \delta^{18} \mathrm{O}$ and $\delta^{2} \mathrm{H}$ need to be comprehensively assessed. The reference water mixing ratio used for normalization should be chosen in the mid-range of atmospheric water mixing ratios expected at the study site. The selected fitting function should be suitable for all isotopes $\left(\delta^{17} \mathrm{O}, \delta^{18} \mathrm{O}, \delta^{2} \mathrm{H}\right)$. We referred to Weng et al. (2020), and used a function of the form $f(x)=a / x+b x+c$. 
3) When analyzing the water standards at low water mixing ratios, a potentially longer persistence of a memory effect needs to be considered. The number of required pre-injections to minimize the memory effect can be inferred from quantitative determination of the memory effect factors, e.g., following Vallet-Coulomb et al. (2021). The performance of at least 20 pre-injections at 20000 ppmv for an isotope difference between two water standards of $15 \%$ limits the impact of the memory effect to the precision of the liquid water standard analysis.

4) The optimum integration time for calibrated atmospheric water vapor isotope data can be estimated from Allan deviation analyses in regard of the precision required for the objective of the study. Short-term variability of the atmospheric water vapor isotope composition should be taken into account. Short integration times of 1-3 minutes are reasonable when analyzing $\delta^{18} \mathrm{O}, \delta^{2} \mathrm{H}$ and d-excess of atmospheric water vapor. For high-precision analyses of ${ }^{17} \mathrm{O}$-excess of atmospheric water vapor $\left(\sigma_{\mathrm{A}}<10\right.$ per meg), integration times of at least 12 minutes are necessary.

\section{Acknowledgements}

460 This study was conducted in the frame of the HUMI-17 project supported by the ANR (grant nos. ANR-17-CE01-0002-01), ECCOREV and labex OT-Med. It benefited from the CNRS human and technical resources allocated to the Ecotrons Research Infrastructure from the state allocation 'Investissement d'Avenir' AnaEEFrance ANR-11-INBS-0001.

\section{References}

Aemisegger, F., Pfahl, S., Sodemann, H., Lehner, I., Seneviratne, S.I., Wernli, H., 2014. Deuterium excess as a proxy for continental moisture recycling and plant transpiration. Atmos. Chem. Phys. 14, 4029-4054. https://doi.org/10.5194/acp-14-4029-2014

Aemisegger, F., Sturm, P., Graf, P., Sodemann, H., Pfahl, S., Knohl, A., Wernli, H., 2012. Measuring variations of $\delta^{18} \mathrm{O}$ and $\delta^{2} \mathrm{H}$ in atmospheric water vapour using two commercial laser-based spectrometers: an instrument characterisation study. Atmos. Meas. Tech. 5, 1491-1511. https://doi.org/10.5194/amt-5-1491-2012

Alexandre, A., Webb, E., Landais, A., Piel, C., Devidal, S., Sonzogni, C., Couapel, M., Mazur, J., Pierre, M., Prié, F., Valletcoulomb, C., Outrequin, C., Roy, J., 2019. Effects of leaf length and development stage on the triple oxygen isotope signature of grass leaf water and phytoliths: insights for a proxy of continental atmospheric humidity. Biogeosciences 16, 4613-4625. https://doi.org/10.5194/bg-16-4613-2019

Aron, P.G., Poulsen, C.J., Fiorella, R.P., Matheny, A.M., 2019. Stable Water Isotopes Reveal Effects of Intermediate Disturbance and Canopy Structure on Forest Water Cycling. J. Geophys. Res. Biogeosciences 124, 2958-2975. https://doi.org/10.1029/2019JG005118

Bailey, A., Noone, D., Berkelhammer, M., Steen-Larsen, H.C., Sato, P., 2015. The stability and calibration of water vapor isotope ratio measurements during long-term deployments. Atmos. Meas. Tech. 8, 4521-4538. 
https://doi.org/10.5194/amt-8-4521-2015

480 Bailey, A., Toohey, D., Noone, D., 2013. Characterizing moisture exchange between the Hawaiian convective boundary layer and free troposphere using stable isotopes in water. J. Geophys. Res. Atmos. 118, 8208-8221. https://doi.org/10.1002/jgrd.50639

Barkan, E., Luz, B., 2005. High precision measurements of ${ }^{17} \mathrm{O} /{ }^{16} \mathrm{O}$ and ${ }^{18} \mathrm{O} /{ }^{16} \mathrm{O}$ ratios in $\mathrm{H}_{2} \mathrm{O}$. Rapid Commun. Mass Spectrom. 19, 3737-3742. https://doi.org/10.1002/rcm.2250

Barkan, E., Luz, B., 2007. Diffusivity fractionations of $\mathrm{H}_{2}{ }^{16} \mathrm{O} / \mathrm{H}_{2}{ }^{17} \mathrm{O}$ and $\mathrm{H}_{2}{ }^{16} \mathrm{O} / \mathrm{H}_{2}{ }^{18} \mathrm{O}$ in air and their implications for isotope hydrology. Rapid Commun. Mass Spectrom. 21, 2999-3005. https://doi.org/10.1002/rcm.3180

Bastrikov, V., Steen-Larsen, H.C., Masson-Delmotte, V., Gribanov, K., Cattani, O., Jouzel, J., Zakharov, V., 2014. Continuous measurements of atmospheric water vapour isotopes in western Siberia (Kourovka). Atmos. Meas. Tech. 7, 1763-1776. https://doi.org/10.5194/amt-7-1763-2014

490 Berkelhammer, M., Hu, J., Bailey, A., Noone, D., Still, C.J., Barnard, H., Gochis, D., Hsiao, G.S., Rahn, T., Turnipseed, A., 2013. The nocturnal water cycle in an open-canopy forest. J. Geophys. Res. Atmos. 118, 10225-10242. https://doi.org/10.1002/jgrd.50701

Berkelhammer, M., Noone, D.C., Wong, T.E., Burns, S.P., Knowles, J.F., Kaushik, A., Blanken, P.D., Williams, M.W., 2016. Convergent approaches to determine an ecosystem's transpiration fraction. Global Biogeochem. Cycles 30, $933-$ 951. https://doi.org/10.1002/2016GB005392

Berner, E.K., Berner, R.A., 2012. Global Environment: Water, Air, and Geochemical Cycles, 2nd ed. Princeton University Press, New Jersey.

Bonne, J.L., Behrens, M., Meyer, H., Kipfstuhl, S., Rabe, B., Schönicke, L., Steen-Larsen, H.C., Werner, M., 2019. Resolving the controls of water vapour isotopes in the Atlantic sector. Nat. Commun. 10, 1-10. https://doi.org/10.1038/s41467-019-09242-6

Bonne, J.L., Masson-Delmotte, V., Cattani, O., Masson-Delmotte, V., Risi, C., Sodemann, H., Steen-Larsen, H.C., 2014. The isotopic composition of water vapour and precipitation in Ivittuut, southern Greenland. Atmos. Chem. Phys. 14, 4419-4439. https://doi.org/10.5194/acp-14-4419-2014

Bousquet, P., Ciais, P., Miller, J.B., Dlugokencky, E.J., Hauglustaine, D.A., Prigent, C., Van Der Werf, G.R., Peylin, P., Brunke, E.G., Carouge, C., Langenfelds, R.L., Lathière, J., Papa, F., Ramonet, M., Schmidt, M., Steele, L.P., Tyler, S.C., White, J., 2006. Contribution of anthropogenic and natural sources to atmospheric methane variability. Nature 443, 439-443. https://doi.org/10.1038/nature05132

Brady, M.P., Hodell, D.A., 2021. Continuous and simultaneous measurement of triple-oxygen and hydrogen isotopes of liquid and vapor during evaporation experiments. Rapid Commun. Mass Spectrom. 35, 1-12. https://doi.org/10.1002/rcm.9078

Brand, W.A., Geilmann, H., Crosson, E., Rella, C.W., 2009. Cavity ring-down spectroscopy versus high-temperature conversion isotope ratio mass spectrometry; a case study on $\delta^{2} \mathrm{H}$ and $\delta^{18} \mathrm{O}$ of pure water samples and alcohol/water 
mixtures. Rapid Commun. Mass Spectrom. 23, 1879-1884. https://doi.org/10.1002/rcm.4083

Bréant, C., Leroy-Dos Santos, C., Agosta, C., Casado, M., Fourré, E., Goursaud, S., Masson-Delmotte, V., Favier, V.,

Cattani, O., Prié, F., Golly, B., Orsi, A., Martinerie, P., Landais, A., 2019. Coastal water vapor isotopic composition driven by katabatic wind variability in summer at Dumont d'Urville, coastal East Antarctica. Earth Planet. Sci. Lett. 514, 37-47. https://doi.org/10.1016/j.eps1.2019.03.004

Casado, M., Landais, A., Masson-Delmotte, V., Genthon, C., Kerstel, E., Kassi, S., Arnaud, L., Picard, G., Prie, F., Cattani, O., Steen-Larsen, H.C., Vignon, E., Cermak, P., 2016. Continuous measurements of isotopic composition of water vapour on the East Antarctic Plateau. Atmos. Chem. Phys. 16, 8521-8538. https://doi.org/10.5194/acp-16-8521-2016

Crosson, E.R., 2008. A cavity ring-down analyzer for measuring atmospheric levels of methane, carbon dioxide, and water vapor. Appl. Phys. B Lasers Opt. 92, 403-408. https://doi.org/10.1007/s00340-008-3135-y

Delattre, H., Vallet-Coulomb, C., Sonzogni, C., 2015. Deuterium excess in the atmospheric water vapour of a Mediterranean coastal wetland: regional vs. local signatures. Atmos. Chem. Phys. 15, 10167-10181. https://doi.org/10.5194/acp-1510167-2015

Fiorella, R.P., Bares, R., Lin, J.C., Ehleringer, J.R., Bowen, G.J., 2018. Detection and variability of combustion-derived vapor in an urban basin. Atmos. Chem. Phys. 18, 8529-8547. https://doi.org/10.5194/acp-18-8529-2018

Gkinis, V., Popp, T.J., Johnsen, S.J., Blunier, T., 2010. A continuous stream flash evaporator for the calibration of an IR cavity ring-down spectrometer for the isotopic analysis of water. Isotopes Environ. Health Stud. 46, 463-475. https://doi.org/10.1080/10256016.2010.538052

Gralher, B., Herbstritt, B., Weiler, M., Wassenaar, L.I., Stumpp, C., 2016. Correcting Laser-Based Water Stable Isotope Readings Biased by Carrier Gas Changes. Environ. Sci. Technol. 50, 7074-7081. https://doi.org/10.1021/acs.est.6b01124

Guilpart, E., Vimeux, F., Evan, S., Brioude, J., Metzger, J.M., Barthe, C., Risi, C., Cattani, O., 2017. The isotopic composition of near-surface water vapor at the Maïdo observatory (Reunion Island, southwestern Indian Ocean) documents the controls of the humidity of the subtropical troposphere. J. Geophys. Res. Atmos. 122, 9628-9650. https://doi.org/10.1002/2017JD026791

Gupta, P., Noone, D., Galewsky, J., Sweeney, C., Vaughn, B.H., 2009. Demonstration of high-precision continuous measurements of water vapor isotopologues in laboratory and remote field deployments using wavelength-scanned cavity ring-down spectroscopy (WS-CRDS) technology. Rapid Commun. Mass Spectrom. 23, 2534-2542. https://doi.org/10.1002/rcm.4100

Hendry, M.J., Richman, B., Wassenaar, L.I., 2011. Correcting for methane interferences on $\delta^{2} \mathrm{H}$ and $\delta^{18} \mathrm{O}$ measurements in pore water using $\mathrm{H}_{2} \mathrm{O}$ (liquid) $\mathrm{H}_{2} \mathrm{O}$ (vapor) equilibration laser spectroscopy. Anal. Chem. 83, 5789-5796. https://doi.org/10.1021/ac201341p

545 Hu, L., Millet, D.B., Mohr, M.J., Wells, K.C., Griffis, T.J., Helmig, D., 2011. Sources and seasonality of atmospheric methanol based on tall tower measurements in the US Upper Midwest. Atmos. Chem. Phys. 11, 11145-11156. 
https://doi.org/10.5194/acp-11-11145-2011

IAEA, 2007. Information Sheet on the new International Measurement Standards VSMOW2 and SLAP2. IAEA Isot. Hydrol. Lab. 2007.

Johnson, J.E., Rella, C.W., 2017. Effects of variation in background mixing ratios of $\mathrm{N}_{2}, \mathrm{O}_{2}$, and $\mathrm{Ar}$ on the measurement of $\delta^{18} \mathrm{O}-\mathrm{H}_{2} \mathrm{O}$ and $\delta^{2} \mathrm{H}-\mathrm{H}_{2} \mathrm{O}$ values by cavity ring-down spectroscopy. Atmos. Meas. Tech. 10, 3073-3091. https://doi.org/10.5194/amt-10-3073-2017

Landais, A., Risi, C., Bony, S., Vimeux, F., Descroix, L., Falourd, S., Bouygues, A., 2010. Combined measurements of ${ }^{17} \mathrm{O}_{\text {excess }}$ and d-excess in African monsoon precipitation: Implications for evaluating convective parameterizations. Earth Planet. Sci. Lett. 298, 104-112. https://doi.org/10.1016/j.eps1.2010.07.033

Landais, A., Steen-Larsen, H.C., Guillevic, M., Masson-Delmotte, V., Vinther, B., Winkler, R., 2012. Triple isotopic composition of oxygen in surface snow and water vapor at NEEM (Greenland). Geochim. Cosmochim. Acta 77, 304316. https://doi.org/10.1016/j.gca.2011.11.022

Lee, X., Kim, K., Smith, R., 2007. Temporal variations of the ${ }^{18} \mathrm{O} /{ }^{16} \mathrm{O}$ signal of the whole-canopy transpiration in a temperate forest. Global Biogeochem. Cycles 21, 1-12. https://doi.org/10.1029/2006GB002871

Leroy-Dos Santos, C., Casado, M., Prié, F., Jossoud, O., Kerstel, E., Farradèche, M., Kassi, S., Fourré, E., Landais, A., 2021. A dedicated robust instrument for water vapor generation at low humidity for use with a laser water isotope analyzer in cold and dry polar regions. Atmos. Meas. Tech. 14, 2907-2918. https://doi.org/10.5194/amt-14-2907-2021

Leroy-Dos Santos, C., Masson-Delmotte, V., Casado, M., Fourré, E., Steen-Larsen, H.C., Maturilli, M., Orsi, A., Berchet, A., Cattani, O., Minster, B., Gherardi, J., Landais, A., 2020. A 4.5 Year-Long Record of Svalbard Water Vapor Isotopic Composition Documents Winter Air Mass Origin. J. Geophys. Res. Atmos. 125, 1-18. https://doi.org/10.1029/2020JD032681

Lin, Y., Clayton, R.N., Huang, L., Nakamura, N., Lyons, J.R., 2013. Oxygen isotope anomaly observed in water vapor from Alert, Canada and the implication for the stratosphere. Proc. Natl. Acad. Sci. 110, 15608-15613. https://doi.org/10.1073/pnas.1313014110

Millar, C., Janzen, K., Nehemy, M.F., Koehler, G., Hervé-Fernández, P., McDonnell, J.J., 2021. Organic contamination detection for isotopic analysis of water by laser spectroscopy. Rapid Commun. Mass Spectrom. 35. https://doi.org/10.1002/rcm.9118

Nehemy, M.F., Millar, C., Janzen, K., Gaj, M., Pratt, D.L., Laroque, C.P., McDonnell, J.J., 2019. ${ }^{17}$ O-excess as a detector for co-extracted organics in vapor analyses of plant isotope signatures. Rapid Commun. Mass Spectrom. 33, 1301-1310. https://doi.org/10.1002/rcm.8470

Outrequin, C., Alexandre, A., Vallet-Coulomb, C., Piel, C., Devidal, S., Landais, A., Couapel, M., Mazur, J., Peugeot, C., Pierre, M., Prié, F., Roy, J., Sonzogni, C., Voigt, C., 2021. The triple oxygen isotope composition of phytoliths, a new proxy of atmospheric relative humidity: controls of soil water isotope composition, temperature, $\mathrm{CO}_{2}$ concentration and relative humidity. Clim. Past Discuss. [preprint], 1-25. https://doi.org/10.5194/cp-2021-34 
Pfahl, S., Wernli, H., 2008. Air parcel trajectory analysis of stable isotopes in water vapor in the eastern Mediterranean. J. Geophys. Res. Atmos. 113, 1-16. https://doi.org/10.1029/2008JD009839

Ranjan, S., Ramanathan, A.L., Keesari, T., Singh, V.B., Kumar, N., Pandey, M., Leuenberger, M.C., 2021. Triple Water Vapour-Isotopologues Record from Chhota Shigri, Western Himalaya, India: A Unified Interpretation based on $\delta^{17} \mathrm{O}$, $\delta^{18} \mathrm{O}, \quad \delta \mathrm{D}$ and Comparison to Meteorological Parameters. Front. Earth Sci. 8, 1-16. https://doi.org/10.3389/feart.2020.599632

Salamalikis, V., Argiriou, A.A., Dotsika, E., 2015. Stable isotopic composition of atmospheric water vapor in Patras, Greece: A concentration weighted trajectory approach. Atmos. Res. 152, 93-104. https://doi.org/10.1016/j.atmosres.2014.02.021

590 Schade, G.W., Goldstein, A.H., 2006. Seasonal measurements of acetone and methanol: Abundances and implications for atmospheric budgets. Global Biogeochem. Cycles 20, 1-10. https://doi.org/10.1029/2005GB002566

Schauer, A.J., Schoenemann, S.W., Steig, E.J., 2016. Routine high-precision analysis of triple water-isotope ratios using cavity ring-down spectroscopy. Rapid Commun. Mass Spectrom. 30, 2059-2069. https://doi.org/10.1002/rcm.7682

Schmidt, M., Maseyk, K., Lett, C., Biron, P., Richard, P., Bariac, T., Seibt, U., 2010. Concentration effects on laser-based 595 $\delta^{18} \mathrm{O}$ and $\delta^{2} \mathrm{H}$ measurements and implications for the calibration of vapour measurements with liquid standards. Rapid Commun. Mass Spectrom. 24, 3553-3561. https://doi.org/10.1002/rcm.4813

Singh, H.B., Salas, L.J., Chatfield, R.B., Czech, E., Fried, A., Walega, J., Evans, M.J., Field, B.D., Jacob, D.J., Blake, D., Heikes, B., Talbot, R., Sachse, G., Crawford, J.H., Avery, M.A., Sandholm, S., Fuelberg, H., 2004. Analysis of the atmospheric distribution, sources, and sinks of oxygenated volatile organic chemicals based on measurements over the Pacific during TRACE-P. J. Geophys. Res. D Atmos. 109, 1-20. https://doi.org/10.1029/2003JD003883

Steen-Larsen, H.C., Johnsen, S.J., Masson-Delmotte, V., Stenni, B., Risi, C., Sodemann, H., Balslev-Clausen, D., Blunier, T., Dahl-Jensen, D., Ellehøj, M.D., Falourd, S., Grindsted, A., Gkinis, V., Jouzel, J., Popp, T., Sheldon, S., Simonsen, S.B., Sjolte, J., Steffensen, J.P., Sperlich, P., Sveinbjörnsdóttir, A.E., Vinther, B.M., White, J.W.C., 2013. Continuous monitoring of summer surface water vapor isotopic composition above the Greenland Ice Sheet. Atmos. Chem. Phys. 13, 4815-4828. https://doi.org/10.5194/acp-13-4815-2013

Steen-Larsen, H.C., Sveinbjörnsdottir, A.E., Jonsson, T., Ritter, F., Bonne, J.L., Masson-Delmotte, V., Sodemann, H., Blunier, T., Dahl-Jensen, D., Vinther, B.M., 2015. Moisture sources and synoptic to seasonal variability of North Atlantic water vapor isotopic composition. J. Geophys. Res. 120, 5757-5774. https://doi.org/10.1002/2015JD023234

Steen-Larsen, H.C., Sveinbjörnsdottir, A.E., Peters, A.J., Masson-Delmotte, V., Guishard, M.P., Hsiao, G., Jouzel, J., Noone, D., Warren, J.K., White, J.W.C., 2014. Climatic controls on water vapor deuterium excess in the marine boundary layer of the North Atlantic based on 500 days of in situ, continuous measurements. Atmos. Chem. Phys. 14, 77417756. https://doi.org/10.5194/acp-14-7741-2014

Steig, E.J., Gkinis, V., Schauer, A.J., Schoenemann, S.W., Samek, K., Hoffnagle, J., Dennis, K.J., Tan, S.M., 2014. Calibrated high-precision ${ }^{17} \mathrm{O}$-excess measurements using cavity ring-down spectroscopy with laser-current-tuned 
cavity resonance. Atmos. Meas. Tech. 7, 2421-2435. https://doi.org/10.5194/amt-7-2421-2014

Surma, J., Assonov, S., Bolourchi, M.J., Staubwasser, M., 2015. Triple oxygen isotope signatures in evaporated water bodies from the Sistan Oasis, Iran. Geophys. Res. Lett. 42, 8456-8462. https://doi.org/10.1002/2015GL066475

Surma, J., Assonov, S., Herwartz, D., Voigt, C., Staubwasser, M., 2018. The evolution of ${ }^{17}$ O-excess in surface water of the arid environment during recharge and evaporation. Sci. Rep. 8, 1-10. https://doi.org/10.1038/s41598-018-23151-6

Surma, J., Assonov, S., Staubwasser, M., 2021. Triple Oxygen Isotope Systematics in the Hydrologic Cycle. Rev. Mineral. Geochemistry 86, 401-428. https://doi.org/10.2138/rmg.2021.86.12

Tian, C., Jiao, W., Beysens, D., Farai Kaseke, K., Medici, M.G., Li, F., Wang, L., 2021. Investigating the role of evaporation in dew formation under different climates using ${ }^{17} \mathrm{O}-$ excess. J. Hydrol. 592, 1-13. https://doi.org/10.1016/j.jhydrol.2020.125847

625 Tian, C., Wang, L., Kaseke, K.F., Bird, B.W., 2018. Stable isotope compositions $\left(\delta^{2} \mathrm{H}, \delta^{18} \mathrm{O}\right.$ and $\left.\delta^{17} \mathrm{O}\right)$ of rainfall and snowfall in the central United States. Sci. Rep. 8, 1-15. https://doi.org/10.1038/s41598-018-25102-7

Tian, C., Wang, L., Novick, K.A., 2016. Water vapor $\delta^{2} \mathrm{H}, \delta^{18} \mathrm{O}$ and $\delta^{17} \mathrm{O}$ measurements using an off-axis integrated cavity output spectrometer - sensitivity to water vapor concentration, delta value and averaging-time. Rapid Commun. Mass Spectrom. 30, 2077-2086. https://doi.org/10.1002/rcm.7714

Tremoy, G., Vimeux, F., Cattani, O., Mayaki, S., Souley, I., Favreau, G., 2011. Measurements of water vapor isotope ratios with wavelength-scanned cavity ring-down spectroscopy technology: New insights and important caveats for deuterium excess measurements in tropical areas in comparison with isotope-ratio mass spectrometry. Rapid Commun. Mass Spectrom. 25, 3469-3480. https://doi.org/10.1002/rcm.5252

Tremoy, G., Vimeux, F., Mayaki, S., Souley, I., Cattani, O., Risi, C., Favreau, G., Oi, M., 2012. A 1-year long $\delta^{18}$ O record of water vapor in Niamey (Niger) reveals insightful atmospheric processes at different timescales. Geophys. Res. Lett. 39, 1-5. https://doi.org/10.1029/2012GL051298

Uechi, Y., Uemura, R., 2019. Dominant influence of the humidity in the moisture source region on the ${ }^{17} \mathrm{O}$-excess in precipitation on a subtropical island. Earth Planet. Sci. Lett. 513, 20-28. https://doi.org/10.1016/j.epsl.2019.02.012

Uemura, R., Barkan, E., Abe, O., Luz, B., 2010. Triple isotope composition of oxygen in atmospheric water vapor. Geophys. Res. Lett. 37, 1-4. https://doi.org/10.1029/2009GL041960

Uemura, R., Matsui, Y., Yoshimura, K., Motoyama, H., Yoshida, N., 2008. Evidence of deuterium excess in water vapor as an indicator of ocean surface conditions. J. Geophys. Res. Atmos. 113, 1-10. https://doi.org/10.1029/2008JD010209

Vallet-Coulomb, C., Couapel, M., Sonzogni, C., 2021. Improving memory effect correction to achieve high precision analysis of $\delta^{17} \mathrm{O}, \delta^{18} \mathrm{O} \delta^{2} \mathrm{H},{ }^{17} \mathrm{O}$-excess and d-excess in water using cavity ring-down laser spectroscopy. Rapid Commun. Mass Spectrom. 35, e9108. https://doi.org/10.1002/rcm.9108

Voigt, C., Herwartz, D., Dorador, C., Staubwasser, M., 2021. Triple oxygen isotope systematics of evaporation and mixing processes in a dynamic desert lake system. Hydrol. Earth Syst. Sci. 25, 1211-1228. https://doi.org/10.5194/hess-25$1211-2021$ 
Wang, L., Caylor, K.K., Dragoni, D., 2009. On the calibration of continuous, high-precision $\delta^{18} \mathrm{O}$ and $\delta^{2} \mathrm{H}$ measurements 650 using an off-axis integrated cavity output spectrometer. Rapid Commun. Mass Spectrom. 23, 530-536. https://doi.org/10.1002/rcm.3905

Wang, L., Caylor, K.K., Villegas, J.C., Barron-Gafford, G.A., Breshears, D.D., Huxman, T.E., 2010. Partitioning evapotranspiration across gradients of woody plant cover: Assessment of a stable isotope technique. Geophys. Res. Lett. 37, 1-7. https://doi.org/10.1029/2010GL043228

655 Wen, X.F., Lee, X., Sun, X.M., Wang, J.L., Tang, Y.K., Li, S.G., Yu, G.R., 2012. Intercomparison of Four Commercial Analyzers for Water Vapor Isotope Measurement. J. Atmos. Ocean. Technol. 29, 235-247. https://doi.org/10.1175/JTECH-D-10-05037.1

Weng, Y., Touzeau, A., Sodemann, H., 2020. Correcting the impact of the isotope composition on the mixing ratio dependency of water vapour isotope measurements with cavity ring-down spectrometers. Atmos. Meas. Tech. 13, 3167-3190. https://doi.org/10.5194/amt-13-3167-2020

Werle, P., 2011. Accuracy and precision of laser spectrometers for trace gas sensing in the presence of optical fringes and atmospheric turbulence. Appl. Phys. B Lasers Opt. 102, 313-329. https://doi.org/10.1007/s00340-010-4165-9

Williams, J., Koppmann, R., 2007. Volatile Organic Compounds in the Atmosphere: An Overview, in: Koppmann, R. (Ed.), Volatile Organic Compounds in the Atmosphere. Blackwell Publishing, Oxford, UK.

665

670

675 
Table 1: Isotope composition of liquid standards (STD) normalized to the VSMOW-SLAP scale, and respective standard deviations (SD) (Vallet-Coulomb et al., 2021). n: number of replicates.

\begin{tabular}{l|ccccc|ccccc|c}
\hline & \multicolumn{5}{|c|}{ MEAN } & \multicolumn{5}{c}{ SD } & \\
STD & $\delta^{17} \mathrm{O}$ & $\delta^{18} \mathrm{O}$ & $\delta^{2} \mathrm{H}$ & ${ }^{17} \mathrm{O}$-excess & $\mathrm{d}$-excess & $\delta^{17} \mathrm{O}$ & $\delta^{18} \mathrm{O}$ & $\delta^{2} \mathrm{H}$ & ${ }^{17} \mathrm{O}$-excess & d-excess & $\mathrm{n}$ \\
& $(\%)$ & $(\%)$ & $(\%)$ & $($ per meg) & $(\%)$ & $(\%)$ & $(\%)$ & $(\%)$ & $($ per meg) & $(\%)$ & \\
\hline \hline ICE & -14.1836 & -26.7411 & -203.05 & 26 & 10.88 & 0.026 & 0.041 & 0.53 & 7 & 0.28 & 4 \\
TAP & -4.5285 & -8.5926 & -59.06 & 18 & 9.68 & 0.017 & 0.021 & 0.49 & 6 & 0.41 & 4 \\
\hline \hline
\end{tabular}


Table 2: Different dry air source configurations. SA: Synthetic Air, AA: Ambient Air. The residual water content specifies the water mixing ratio of the dry air source indicated by the laser spectrometer.

\begin{tabular}{|c|c|c|c|c|c|}
\hline Acronym & SA-40 & $\mathrm{AA}_{\text {port }}-\mathbf{4 0}$ & AA $A_{\text {stat-40 }}$ CO2-free & AAstat-100CO2-free & $\mathbf{A A}_{\text {stat }}-300$ CO2-free \\
\hline Dry air source & synthetic air & ambient air & ambient air & ambient air & ambient air \\
\hline $\begin{array}{l}\text { Residual water } \\
\text { content (ppmv) }\end{array}$ & $<40$ & $<40$ & $<40$ & $100-120$ & $300-350$ \\
\hline \multirow{5}{*}{ Drying system } & \multirow{5}{*}{-} & $\begin{array}{l}\text { portable } \\
\text { compressor, }\end{array}$ & $\begin{array}{l}\text { stationary } \\
\text { compressor, }\end{array}$ & $\begin{array}{l}\text { stationary } \\
\text { compressor, }\end{array}$ & $\begin{array}{l}\text { stationary } \\
\text { compressor, }\end{array}$ \\
\hline & & $\begin{array}{c}\text { activated } \\
\text { charcoal filter, }\end{array}$ & $\mathrm{CO}_{2}$ trap, & $\mathrm{CO}_{2}$ trap, & $\mathrm{CO}_{2}$ trap, \\
\hline & & 2 drierite units, & $\begin{array}{l}\text { activated charcoal } \\
\text { filter, }\end{array}$ & $\begin{array}{l}\text { activated charcoal } \\
\text { filter, }\end{array}$ & $\begin{array}{l}\text { activated charcoal } \\
\text { filter }\end{array}$ \\
\hline & & $\mathrm{MgClO}_{4}$ column, & 2 drierite units, & 2 drierite units, & \\
\hline & & dry ice trap & $\begin{array}{c}\mathrm{MgClO}_{4} \text { column, } \\
\text { dry ice trap }\end{array}$ & $\mathrm{MgClO}_{4}$ column & \\
\hline
\end{tabular}


Table 3: Raw isotope data obtained for the two water standards (ICE and TAP) at water mixing ratios of 6000 and 25000 ppmv using the different dry air source configurations described in Table 2. $\mathrm{H}_{2} \mathrm{O}$ : water mixing ratio of the analysis, SD: standard deviation, $n$ : number of replicates.

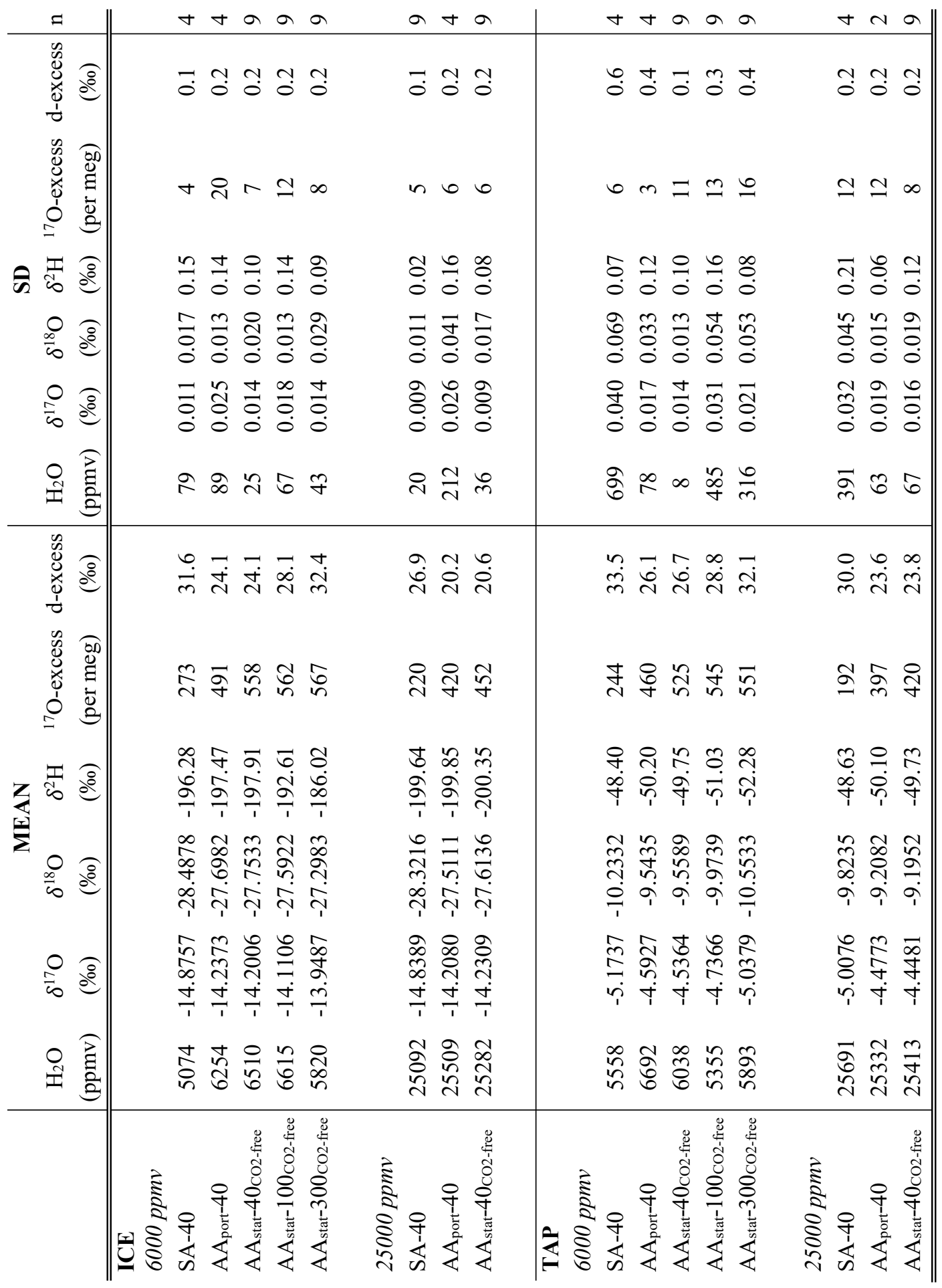


Figure captions:

Figure 1: Impact of the chemical composition of the dry air source (Table 2) on raw isotope data obtained for ICE (left) and TAP (right) analyzed at water mixing ratios of 6000 and 25000 ppmv. Each data point represents the mean and standard deviation (SD) of six injections. Note that triple oxygen isotope data in panel (a)-(d) is displayed in $\delta^{\prime}$ notation $\left(\delta^{\prime}=1000 \cdot \ln (\delta / 1000+1)\right.$.

Figure 2: Impact of the residual water in the dried ambient air source (Table 2) on the raw isotope data obtained for ICE (left) and TAP (right) analyzed at a water mixing ratio of $6000 \mathrm{ppmv}$. Each data point represents the mean and standard deviation (SD) of six injections. Note that triple oxygen isotope data in panel (a)-(d) is displayed in $\delta^{\prime}$ notation $\left(\delta^{\prime}=1000 \cdot \ln (\delta / 1000+1)\right.$.

Figure 3: Mixing ratio dependencies of raw isotope data obtained for TAP (red) and ICE (blue) using SA-40 (dark color) and AA (light color). Measurements were performed at injection volumes of $0.2,0.3,0.4,0.5,0.6,0.7,1.0,1.3,1.6,1.9$, and 2.2 $\mu$. Values are normalized to those obtained at a reference mixing ratio of $10000 \mathrm{ppmv}$. Solid lines show the respective mixing ratio dependency

745 functions calculated for the mixing ratio range between 2000 and 30000 ppmv.

Figure 4: Allan deviations for $\delta^{17} \mathrm{O}, \delta^{18} \mathrm{O}, \delta^{2} \mathrm{H},{ }^{17} \mathrm{O}$-excess and d-excess calculated for 24-hour measurements of a stable water vapor source supplied by a dew-point generator. The shaded area indicates the optimum integration time window.

Figure 5: 12 min-integrated atmospheric water vapor isotope data obtained at the Ecotron. The data were calibrated following the procedure described in Section 2.4 with ICE and TAP analyzed using SA-40 (orange curves) and AA $\mathrm{A}_{\text {port }}-40$ (green curves). Raw isotope data (black curve) are shown for comparison. 